Research Paper

\title{
A Comparison of the Educational Methods of Zoltán Kodály and his Student, Klára Kokas
}

\author{
Imola Csilla Székely ${ }^{1}$ \\ Recommended citation: \\ Székely, Cs. I. (2021). A Comparison of the Educational Methods of Zoltán Kodály and his Student, Klára Kokas. Central \\ European Journal of Educational Research, 3(1), 47-52. https://doi.org/10.37441/CEJER/2021/3/1/9350
}

\begin{abstract}
After the presentation of Klára Kokas' pedagogical methods and her own invented musical activities with children, I shall try to compare these methods with Zoltán Kodály's music educational practices and innovations to emphasize the continuity and discontinuity of Hungarian music educational practice. Kokas centered her pedagogical concept on children's creativity, human relations, acceptance of and complete attention paid to others. This world view and ideology was constructed around a child-centered sensitivity, music being her primary pedagogical resource. The goal of this paper is to explore the main elements and characteristics of Klára Kokas's pedagogy, which were revolutionary and new in the fields of personality development, music and complex art education. I will draw out those elements, which show similarity between his work and Kokas's, then I will point out those components in which Kokas offered excess for personality development. The main elements of this concept is music, dance improvisation, motions, imaginative stories, visual arts, painting and drawing, but it's most important component is that very specific and intimate relation, which connected her to the children. My purpose is to highlight the contours of the Kokas' pedagogy. In my comparative research I mention the reform pedagogical elements of the Zoltán Kodály's concept, and I seek the common and different elements of their music educational ideas and innovations. The importance of her beliefs and moral convictions in the art of education will be outlined then.
\end{abstract}

Keywords: Klára Kokas; music education; complex art pedagogy

\section{Introduction}

The music pedagogue and music psychologist Klára Kokas (1929-2010) was one of Kodály’s students at Liszt Ferenc Academy of Music in Budapest. She was continuing Kodály's concept in music education, in addition she transformed, enriched and combined it with other fields of human artistic activities. In my presentation I will summarize the pedagogical methods of Klára Kokas and her own invented musical activities with children, while I try to compare them with Zoltán Kodály's music educational practices and innovations to emphasize the continuity and discontinuity of Hungarian music educational practice.

My purpose is to highlight the contours of the Kokas' pedagogy. In my comparative research I mention the reform pedagogical elements of the Zoltán Kodály's concept, and I look for the common and different elements of their music educational ideas and innovations - there are elements which show similarity between Kodály's and Kokas's concepts, but she emphasized the role of music in personality development. Kokas centered her pedagogical concept on children's creativity, human relations, acceptance of and complete attention paid to others. This world view and ideology was constructed around a child-centered sensitivity, music being her primary pedagogical resource.

\footnotetext{
${ }^{1}$ University of Debrecen, Hungary; szcsillaimola@gmail.com
} 


\section{Music pedagogical methods of Klára Kokas}

Klára Kokas consciously used the ceremonial repetitions of rites in her teachings, but her music classes were never rigid or dictated by her methodology. They can be characterized by the free flow of ideas and emotions. Our ears are only a medium of mediation because we do not listen to music with the ear, but with the heart. "To supply children with a framework in recurrent forms is part of a teacher's craft, because children need touchstones which can be anticipated and which thus give security" (Kokas, 1999:35). They grant the feeling of being home to the children: "They find peace in our order, because the well-known is important for them - it saves them from the trial of continually having to face up to unexpected situations" (Kokas, 1999:37). A kind of endlessness, incompleteness characterizes Kokas's sessions because they are open-minded, freeflowing, adaptable and infinite.

Elements of the music pedagogical methods of Klára Kokas are the following:

- $\quad$ carefully selected valuable music material;

- creation of experience;

- $\quad$ freedom to use space, choose activities, techniques and partner;

- $\quad$ clarified framework;

- $\quad$ respect of another's personality;

- creating the atmosphere of trust, confidence;

- acceptance of other's uniqueness as valuable;

- $\quad$ rites as repeated order of activities - recurring occupational order, rituals (Deszpot, 2017).

- Characteristic elements and order of the entire Kokas program

Welcome songs, name singing, folk songs

She always began her lessons with singing, generally well-known folk songs, in which they creatively placed each child's name. This was meant to be the entrance into the activity, the calming immersion in the world of music. "Greetings are names sung to traditional melodies or freely improvised tunes. They may also take the form of salutation, celebration, or commemoration. Complementing gaze and touch, they are a voiced means of establishing contact which is made intimately personal by them" (Kokas, 1999:20).

\section{Free movement to songs, singing circle games}

They were also learning new folk songs. Their actions were never a simple reproduction, but rather Kokas and the participants were curious about everybody's individual variation of song and dance. Their own special ideas and inventions were truly valuable to Kokas: "The improvised tune gives a chance to confirm the beautiful pentatonic phrases, to change pitch in an adventurous spirit, to play with rhythm, to express emotions, to find out new tempo and dynamic variations" (Kokas, 1999:19). These represent the archetypical psychological processes and rituals at the same time, which have fundamental importance in children's personality development (Holger, 2011).

\section{Waiting for silence and listening to music}

After they found everyone's spiritual silence by listening to instrumental music, they were able to feel the music and hear its message. True and receptive listening to music can only start from silence of the spirit - says Kokas. At this moment they were encouraged to comfortably sit or lie down however they wanted, but be perfectly silent.

In this position they listened to the brief one or two-minute-long pieces of classical music over and over again about five or more times until they discovered every part of it like a pleasant landscape. These pieces of music can be characterized by quality, esthetic standards and varied tempo. The repertoire is very colorful and rich: "Nearly half of our music collection is folk music - not only Hungarian in origin but also belonging to the most diverse nations. (...) Our songs are all Hungarian folk-songs from game-songs to ancient ballads and laments. They are an important part of our mother tongue, rich treasures that have been systematically excavated and described in all detail" (Kokas, 1999:47).

In addition to the above, her music collection included a long list of early-renaissance pieces as well as baroque and Gregorian melodies, and a variety of works of contemporary composers. The following are the artists she drew from: Corelli, J.S. Bach, Händel, Vivaldi, Albinoni, Telemann, Monteverdi, Mozart, Haydn, 
Beethoven (primarily his chamber music), Schubert, Schumann, Brahms, (fewer from Wagner, Liszt, Berlioz), Chopin (etudes, preludes, piano concerts), Debussy, Ravel, Dvorak, Smetana, Fauré, Kodály (chamber music, cello sonata), Bartók (Microcosmos), Kurtág, Ligeti, Steve Reich (Kokas, 1999).

\section{Setting improvisational dance and motion to music}

Dance at Kokas sessions has always been a community activity even when a child was dancing a solo. When the music was internalized by the children, they started to dramatize it with their motion and dance, while they were inventing their individual roles. Her students called "these emotionally intense moments of identification shape-changing” (Kokas, 1999:27).

Music is able to unintentionally bring the enriching effects of its spiritual message to the surface by motions and emotions. Like a girl said: "music raises my hands". And it can also free adults from inhibitions. Music is able to provide space for the subconscious (Szabó, 2008). Children related beautiful stories this way, which were wordless descriptions of the music using their bodies and imagination. These reflected an entire imaginary world which music opened the door to.

After the music ended, children had the opportunity to tell their story to everyone, which was then recorded by the multimedia technological devices of the age. This is how it was written in her book titled "Music Raises My Hands" in 1992 (Kokas, 1992) and her posthumously published work entitled "I Combed the Clouds" in 2012 (Kokas, 2012).

"Movement is just as natural an activity for us humans as is uttering sound. Our concept of training should be built upon those primary, sensuous experiences - the natural condition of our being - which occur incessantly and are mutually interactive and complementary" (Kokas, 1999:20). This is why we need to develop the movement expression of our students so much, and it is as important as the development of their verbal communication. "An interaction - an organic but flexible connection - is established between motion and music, which is confirmed by the repetitions. Thus body and soul become partners in exploring the vibrating world of music" (Kokas, 1999:22).

\section{Acting out the movement composition. Visualization: drawing the story}

While children were creating works by drawing, painting and sculpting to music, in their minds there were multiple associations, and music somehow appeared in their artwork. These activities took place not only inside a room, but also out on a field, at the seaside or in a church as well. They often used not only brushes, but also their hands, fingers or whatever they wanted - always to music. Movements were also part of the events and craftworks - so the whole activity could be named complex art therapy.

After the music ended, children could speak about their inner feelings and inspirations during the artwork or the entire session again - because while the activities were proceeding, only music could be heard.

\section{Narration about the dance and picture}

It's important to mention that Klára Kokas's questions never directed the children's answers, but she always encouraged them like she was opening the doors to their creativity and imagination. Meanwhile she was waiting with sincere curiosity for the surprising ending. During her conversation with her disciples, she paid strong attention to their souls. Music was the connection between the education and therapeutic effects, because their common roots met within the territory of music.

\section{Farewell, candle light and goodbye-singing}

The complex art educational sessions always had a closing part: the group farewell singing by candlelight. They sang folk songs, but this time they could have their special requests, and then blew out the candle together. This is a ritual element of the complete session, because everyone would like to remain in the hearts of others until the next meeting. Sitting in a circle and singing together reminds everybody of the intimate family-like atmosphere, and the participants feel at home in the presence of the others (Kokas, 1992). These are tranquil moments when the comforting closing tunes encourage everyone to look forward to the next meeting. "Parting songs are the final cadences of the lessons, following the lively, dynamic period of creative efforts. They are used in the last minutes when we seek peace and calm. The call for the parting song comes from the lighted candle, from the position of rest taken by those around it, and the concentration shared by all" (Kokas, 1999:20). 


\section{Comparing analysis - Zoltán Kodály and Klára Kokas}

Zoltán Kodály (1882-1967), recipient of the Kossuth Prize, composer, music pedagogue and ethnomusicologist, the director of the Hungarian Academy of Sciences, deeply believed in the power of the soul-breeding catharsis, and he believed that aesthetics develops morality and forms the character (Kodály, 1982; Pukánszky). He shaped his music pedagogical and lifestyle management method, which raised him to worldwide recognition.

In the development of the Kokas pedagogy, Kodály was one of her models. He was present as a base, a starting point, a source of inspiration. She referred to him as a personal mentor, and a master. Both of them believed that only high quality music from pure sources could nourish and maintain the soul (Holger, 2011). The method of Klára Kokas is built upon Kodály's educational concept in a direct and original way, which is a concrete and special methodological realization of it (Deszpot, 2014). The Kokas method has, in addition to the Kodály concept, the improvisation part, which can touch the children more readily than in the Kodály classes. These "identification shape-changing" dances and the craftworks done to music increase the children's sensitivity throughout their bodies (Holger, 2011). "According to Kodály, culture cannot be inherited, but must be re-learnt by every generation” (Váradi, 2014; Kodály, 1982).

Music education through the Kodály concept is a more cognitive approach to music. This is the point where the Kokas method completes the previous music education, because she emphasizes the emotional elements and message of the music. It is often said that the basis of music pedagogy is not just the method anymore, but the philosophy, for example, Kodály's teaching about the role of music in society and the life of children, teenagers and adults (Szőnyi, 2014).

This contrasts with the method of Klára Kokas whose aim was the development of personality and creativity through her complex art pedagogy, movement associations, improvisational dances and manual arts: "My aim was to adjust the children's musical experience to movement. I tried to liberate their stiff motions the result of their unfortunate physical condition - in all the possible ways I could find" (Kokas, 1999:31). This is why she doesn't teach either (absolute, nor relative) solmization, or music literacy like Kodály does. Instead, she teaches folk songs only through listening and personal experience.

Kokas asked the children not only to reproduce the songs but also to apply variation. So they changed some words or lines of the original Hungarian folk songs in a most playful and delightful way. They played these singing games with a new meaning, in other words they were improvising. On the other hand, children in Kodály's choruses weren’t encouraged to move or interpret music by showing their emotions.

\section{The characteristics of Klára Kokas' pedagogy are the following:}

Creativity development through music - not music education in a classic way, but rather personal development with music, therapy, empathy, absolute attention, improvisational shape-changing dances, motional-verbal-visual representation, spontaneous self-expression, association to music, folk song and name singing, circle games, the importance of imagination in education, free choice of partner or technique, complex art pedagogy, qualitative and absolute classical instrumental music, transfer effect, trusting and intimate atmosphere. 


Zoltán Kodály
Kodály recommended beginning music education at
the youngest age with selected musical pieces, and
even when the child was inside the mother's womb.
Singing as actively making music is the closest to us
humans. The human voice is the noblest
instrument, and so we need to develop people's
inner hearing.
Kodály focuses on folk traditions and cultural
treasures (Hungarian pentatonic scale) and said that
we get to know our musical native language through
our folk songs.

Choir and group folk song singing: music should be a community experience, for example through choir singing. The aim is to connect people to valuable music, and Kodály's answer, singing in choir, is the best way (Kodály, 1937).

Music belongs to everyone! (Kodály, 1982). In other words everyone should have access to music education and music literacy. The aim is a musically educated society.

Although Kodály in his teachings encouraged his students to include other artistic fields, his concept wasn't focused on the complexity of it. Kodály's point of view was that valuable music makes the human spirit more sensitive to the reception of artistic beauty and it has a taste-developing power.

Less energetic - although Kodály declared that music is inseparable from movement, he didn't encourage it. Choir members didn't move or improvise while they were singing.

Relative solmization - practice of music literacy (musical reading and writing), which Kodály always developed together with the inner hearing (Kodály, 1982; Pethö, 2011).

Only artistic, high-quality, pure music should be the basis of music education. The central aspect of it and people's meeting with music should be valueoriented and guarantee it will always be with their

own original musical language, their "mother tongue of music". Kodály said: children ought to be offered only the highest artistic values!

(Gyermekkarok, 1929 - Kodaly.hu)

Kodály' approach to music is more cognitive.

He hypothesized that music has multiple transfer effects - every child can be developed musically (Kodály, 1982).
Klára Kokas

The participants of the Kokas sessions are little children of kindergarten and pre-school age. But Kokas had adult groups also - she held sessions with parents and grandparents.

Kokas encouraged singing and active listening to musical pieces from the most noble international musical traditions.

Child-centered education - they learn folk songs, circle games and other skills, but the most important dimension of her teachings is the attentive and active music internalization.

"Singing is my mother tongue" (Kokas, 1999:19) developed through community games, folk songs and name singing.

Kokas's aim was to lead people to music, to educate the participants in her sessions to be a musicconscious audience who feels the music.

Complex skill and personality development motional-verbal-visual expression. This represents its novelty by combining music with movement and visualization: improvisational dance, molding.

Dynamic - there was opportunity for improvising, personal, individual and community activities, for self-expression in combining music with movement and dance.

There is neither solmization, nor musical reading and writing education, but only experimental folk song singing and learning through listening.

On this topic the Kokas method is similar to Kodály's beliefs. She applies the artistic, pure folk song tradition and absolute music repertoire.

Kokas concentrated on the emotional message of music.

On the other hand, Kokas measured and proved the transfer effects of music. This was her $\mathrm{PhD}$ dissertation topic entitled "Skill Development Through Music Education” (1972).

\section{Conclusion}

Because of its complexity, the art pedagogical method of Klára Kokas was revolutionary in the fields of personality development. The main elements of this concept are music, dance improvisation, movement, imaginative stories, visual arts, painting and drawing. Its most important component is that very specific and intimate relationship, which connected her to the children.

In conclusion we can confirm that before Kokas invented her associative and music educational approach, similar reforms already existed in music pedagogy, whose elements showed some similarities to hers, but each of these methods brought new ideas and aspects to the field of music education. Klára Kokas added 
free movement to music to the classical way of teaching folk songs provided from pure sources. This combined with her spirituality and religiousness, her attention and curiosity, the entire self, an unspeakable and profoundly personal relationship and inspirational trust, she taught her disciple's sensitivity and empathy to others, she showed them how to be entirely present and to express their innermost emotions.

The most specific of Kokas's peculiarities was includin not only Hungarian pieces in her music repertoire, but other nations' folk music too, not to mention the absolute freedom of movement and improvisational dances to music, the narratives about the dances and handmade works of the children. All of these were a combination of reality and fantasy, that extremely sensitive relationship of trust which gave wings to her children's imagination.

\section{References}

Deszpot, G. (2014). Mozgás és zeneolvasás Kokas-pedagógiával. [Movement and Music Reading with Kokas Pedagogy]. Budapest: Ferenc Liszt Academy of Music, Kodály Institute.

Deszpot, G. (2017). Zenei átváltozás. Kokas Klára komplex múvészeti programja mint pedagógia és terápia [Musical shapechanging Klára Kokas's Complex Art Program as Pedagogy and Therapy]. Magyar Pedagógia, 51(6), 5-11. Retrieved April 2, 2020, from http://www.parlando.hu/2009-6-02-03-Kokas-Klara-1.html

Holger, A. (2011). The Case for Movement in Children's Music Education. (Unpublished doctoral dissertation). Ferenc Liszt Academy of Music, Kodály Institute.

Kodály, Z. (1982). Visszatekintés I. [Retrospection I.]. Budapest: Zenemúkiadó Vállalat.

Kokas, K. (1972). Képességfejlesztés zenei neveléssel [Skill development through music education]. Budapest: Zenemükiadó

Kokas, K. (1992). A zene felemeli kezeimet [Music raises my hands]. Budapest: Akadémiai Kiadó. In: Kokas, K., Lájer, Jné., Furka, B. \& Kocsis, M. (2007). Öröm, büvös égi szikra. Multimédiás DVD-rom tanitásaimról. [Joy Through the Magic of Music. A multimedia DVD-rom about my teachings]. Budapest: Copyright Edition.

Kokas, K. (1999). Joy Through the Magic of Music. Budapest: Akkord Zenei Kiadó.

Kokas, K. (2012). Megfésültem a felhöket [I Combed the Clouds]. Budapest: Kokas Klára Agape Zene-Életöröm Alapítvány [Klára Kokas Agape Music-Joy of Life Foundation].

Pethő, V. (2011). Kodály Zoltán és követői zenepedagógiájának életreform elemei [The Life Reform Elements of the Music Pedagogy of Zoltán Kodály and His Followers]. (Unpublished doctoral dissertation). University of Szeged. Retrieved April 5, 2020, from http://www.edu.u-szeged.hu/phd/downloads/pethov_ertekezes.pdf

Pukánszky, B. (s.a.). Kodály Zoltán zenepedagógiai munkásságának életreform motívumai [The Life Reform Motifs of the Music Pedagogy Works of Zoltán Kodály]. Retrieved April 15, 2020, from http://www.pukanszky.hu/Kodaly.pdf

Szabó, O. (2008). A tested zene [Your Body is Music] (Unpublished doctoral dissertation). Budapest: Ferenc Liszt Academy of Music. Retrieved April 12, 2020, from https://www.parlando.hu/2015/2015-3/SzaboOrsolyaTested_zene_disszertacio.pdf

Szőnyi, E. (2008). Kodály Zoltán tanári egyénisége, nevelési koncepciójának hazai és nemzetközi elterjedése [Zoltán Kodály's Teacher Personality and the National and International Spread of His Educational Concept]. Debreceni Szemle, (16), 368-373. Retrieved April 5, 2020, from http://szemle.unideb.hu/wordpress/wp-content/uploads/bskpdf-manager/397_2014-08-19.PDF

Váradi, J. (2014). A zenei nevelés gyökerei [Roots of the Music Education]. Doktori disszertáció, 1-16. Retrieved April 5, 2020, from http://www.parlando.hu/2014/2014-2/VaradiJudit-Zeneineveles.pdf

Webpage: Liszt Academy Kodály Institute, Kodály Concept. Retrieved from https://kodaly.hu/kodaly_en_kodaly/kodalyconcept-107384

(C) 2021 by the authors. Submitted for possible open access publication under the terms and conditions of the Creative Commons Attribution (CC BY) license (http://creativecommons.org/licenses/by/4.0/). 